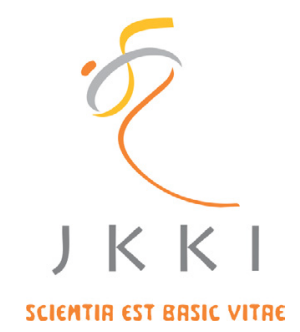

Jurnal Kedokteran dan Kesehatan Indonesia

Indonesian Journal of Medicine and Health

Journal homepage : https://journal.uii.ac.id/JKKI

\title{
Regional pericarditis with reciprocal ECG changes mimicking inferior ST-elevation myocardial infarction (STEMI): a case report
}

Gilang Mauladi Rahman*1, Mochammad Yusuf Alsagaff ${ }^{2}$

${ }^{1}$ Cardiology and Vascular Medicine Resident, Faculty of Medicine, Universitas Airlangga - dr. Soetomo General Hospital, Surabaya, Indonesia

${ }^{2}$ Cardiologist, Department of Cardiology and Vascular Medicine, Faculty of Medicine, Universitas Airlangga - dr. Soetomo General Hospital - Airlangga University Hospital, Surabaya, Indonesia

Case Report

\begin{tabular}{|c|c|}
\hline & $A B$ \\
\hline ARTICLE INFO & \multirow{6}{*}{$\begin{array}{l}\text { Acute pericarditis is generally presented with a chest pain and a diffus } \\
\text { ST-segment elevation in ECG. Focal ST-segment elevation due to localisec } \\
\text { inflammation of pericardium in regional pericarditis could resemble } \\
\text { ST-elevation myocardial infarction (STEMI). A case in this study was } \\
\text { 30-year-old man in emergency room as a surgery resident experiencing } \\
\text { recently acute typical chest pain. He had a history of smoking withou } \\
\text { other cardiovascular disease risk factors. ECG immediately was conducted } \\
\text { and it revealed ST-segment elevation in an inferior lead with reciproca } \\
\text { ST-segment depression in aVL, which was typical for an inferior STEMI } \\
\text { Primary PCI was conducted, and it surprisingly revealed a normal coronary } \\
\text { artery. Serial serum cardiac biomarkers found a normal cardiac troponin- } \\
\text { level (<0.001 mcg/L) and did not significantly change after seria } \\
\text { examinations. We treated the patient as a suspect of coronary spasm with } \\
\text { calcium-channel blockers and nitrates. After three days of hospitalization } \\
\text { the patient was discharged from the hospital, and he planned to ge } \\
\text { cardiac magnetic resonance (CMR). The CMR was conducted after sever } \\
\text { days of the discharge, and it revealed a loculated pericardial effusior } \\
\text { leading to regional pericarditis. The patient was treated with empirica } \\
\text { NSAIDs for three weeks. Clinical and echocardiographic evaluation afte } \\
\text { the treatment showed an excellent result. A presence of focal ST-segmen } \\
\text { elevation with reciprocal ST-segment depression was generally consisten } \\
\text { with the STEMI, but this case was an exception. Although rare, regiona } \\
\text { pericarditis can be a differential diagnosis in a patient with acute ches } \\
\text { pain with a focal ST-segment elevation. }\end{array}$} \\
\hline $\begin{array}{l}\text { Keywords: } \\
\text { regional, } \\
\text { pericarditis, } \\
\text { reciprocal, } \\
\text { changes, } \\
\text { mimicking, } \\
\text { STEMI }\end{array}$ & \\
\hline $\begin{array}{l}\text { *Corresponding author: } \\
\text { gilangmauladirahman@gmail.com }\end{array}$ & \\
\hline DOI: 10.20885/JKKI.Vol11.Iss1.art13 & \\
\hline $\begin{array}{l}\text { Received: March 19, } 2019 \\
\text { Accepted: March 10, } 2020 \\
\text { Online: April 30, } 2020\end{array}$ & \\
\hline $\begin{array}{l}\text { Copyright @2020 Authors. } \\
\text { This is an open access article } \\
\text { distributed under the terms } \\
\text { of the Creative Commons At- } \\
\text { tribution-NonCommercial } 4.0 \\
\text { International Licence (http:// } \\
\text { creativecommons.org/licences/ } \\
\text { by-nc/4.0/). }\end{array}$ & \\
\hline
\end{tabular}

Perikarditis akut umumnya datang dengan presentasi klinis nyeri dada dan elevasi segmen-ST difus pada EKG. Elevasi segmen-ST fokal yang terkait dengan inflamasi perikard yang terlokalisir dapat menyerupai gambaran STEMI. Kasus: laki-laki berusia 30 tahun seorang residen bedah yang sedang bertugas di Instalasi Gawat Darurat (IGD) datang dengan keluhan nyeri dada tipikal akutyang baru saja dirasakannya. Dia memiliki riwayat merokok, tanpa faktor risiko penyakit kardiovaskuler lainnya. Pemeriksaan EKG segera dilakukan dan menunjukkan suatu elevasi segmen-ST pada lead inferior dengan depresi segmenST resiprokal di lead aVL yang khas untuk STEMI inferior. PCI primer segera dilakukan dan secara mengejutkan menunjukkan hasil yang normal. Pemeriksaan biomarker troponin-I menunjukkan hasil yang normal (<0.001 mcg/L) dan tidak berubah secara signifikan pada pemeriksaan serial. Kami rawat 
pasien sebagai suspek spasme koroner dengan terapi calcium-channel blockers dan nitrat. Setelah tiga hari perawatan, pasien keluar dari rumah sakit dan direncanakan untuk menjalani pemeriksaan MRI jantung. MRI jantung dilakukan tujuh hari kemudian dan didapatkan hasil efusi perikard terlokulasi mengarah pada perikarditis regional. Pasien ditatalaksana dengan obat antiinflamasi non steroid (OAINS) empiris selama tiga minggu. Evaluasi klinis dan ekhokardiografi paska terapi menujukkan hasil yang sangat baik. Adanya elevasi segmen-ST fokal disertai dengan depresi segmen-ST resiprokal biasanya mengarah ke STEMI, namun kasus ini merupakan pengecualian. Meskipun jarang, perikarditis regional dapat menjadi diagnosis banding pada pasien dengan nyeri dada akut disertai dengan elevasi segmen-ST fokal.

\section{INTRODUCTION}

Acute pericarditis is an inflammation of a pericardium generally presented with chest pain, pericardial friction rubs, and typical ECG changes. It is diagnosed in approximately $0.1 \%$ hospitalised patients with chest pain. ${ }^{1}$ The most common aetiology of pericarditis in developed countries is viruses, whereas tuberculosis is the most frequent cause in developing countries. ${ }^{2}$ Pericarditis is the most common form of pericardial diseases which typically affect young and middle-aged people, and it is usually suffered by men of 20 to 50 year old. ${ }^{1}$

A clinical diagnosis of acute pericarditis can be conducted based on two of the following criteria: a) pericardial chest pain, b) pericardial friction rub, c) typical ECG changes, and d) pericardial effusion (new or worsening). ${ }^{2}$ A chest pain of acute pericarditis is usually sudden in onset, pleurisy, and felt in retrosternal. An audible pericardial friction rub, that presents in $85 \%$ of patients, is highly specific for pericarditis. A pericardial friction rub is a high-pitched, scratchy or squeaky sound heard at the left sternal border. Typical ECG changes in acute pericarditis include wide-spread upward concave ST-segment elevation and PR-segment depression. The finding of pericardial effusion in transthoracic echocardiogram (TTE) supports the diagnosis and guides further management. ${ }^{2,3}$

ECG changes related to pericardial inflammation occur in approximately $90 \%$ of patients with acute pericarditis. Typical ECG changes include classic diffuse concave upward ST-segment elevation and PR segment depression without $\mathrm{T}$ wave inversion. In contrast, regionally distributed convex ST-segment elevation with or without pathologic $Q$ waves and reciprocal ECG changes commonly occur in STEMI. ${ }^{1,4}$ Although diffused ST-segment elevation is typical for pericarditis, focal STsegment elevation due to localised inflammation of pericardium in regional pericarditis can resemble the STEMI. ${ }^{5}$ This case report presents a case of regional pericarditis with clinical and electrocardiographic presentations that are nearly indistinguishable to the STEMI.

\section{CASE REPORT}

A 30-year-old man in the emergency room as a surgery resident experienced acute typical chest pain ( 2 hours of onset) and became worsened until he took a medical evaluation. He had a history of smoking without other cardiovascular risk factors. There was no history of trauma, tuberculosis, systemic inflammatory disease, or malignancy. His vital signs were stable, and there was no abnormality of his physical examination. ECG examination immediately was conducted, and it revealed ST-segment elevation in the inferior lead with reciprocal ST-segment depression in aVL (Figure1). Then a diagnosis of interior STEMI had been made. A primary percutaneous coronary intervention (PCI) immediately was conducted as a primary PCI-capable hospital. Before the PCI, a diagnostic coronary angiography (DCA) was routinely conducted to evaluate his coronary anatomy and the presence of blood flow obstruction. The DCA surprisingly revealed a right dominant normal coronary artery without any supporting evidence of coronary obstruction (Figure 2), so the PCI was not conducted. Serial serum cardiac biomarkers found a normal cardiac troponin-I level $(<0.001$ $\mathrm{mcg} / \mathrm{L}$ ) and did not significantly changed after serial examinations. The researchers began conservative therapies with calcium-channel blockers (diltiazem slow release $200 \mathrm{mg}$ per 
day) and nitrates (isosorbide dinitrate $5 \mathrm{mg}$ twice a day) as a suspect of coronary spasm. After three days of hospitalisation, the patient was discharged and was planned to perform cardiac magnetic resonance (CMR) imaging. The CMR was conducted seven days after the discharge, and it revealed a normal left ventricle function and dimension. Pericardial effusion was loculated at the left apical and right free wall without pericardial thickening (Figure 3A). T2 weighted images showed no increased signal intensity in the myocardium but marked pericardial enhancement (Figure 3B). Early gadolinium enhancement image showed no thrombus detected as intracavity. Late gadolinium enhancement image showed no hyperenhancement in the myocardium. The summary of the CMR examination presumed that the patient experienced regional pericarditis. The patient was treated with empirical non-steroidal anti-inflammatory drug (NSAIDs), ibuprofen 800 mg three times a day for three weeks. Clinical and TTE evaluation was conducted after the treatment revealed a preserved left and right ventricle function without sequels of the last illness. The patient was asymptomatic without evidence of pericardial effusion or constrictive pericarditis on TTE.

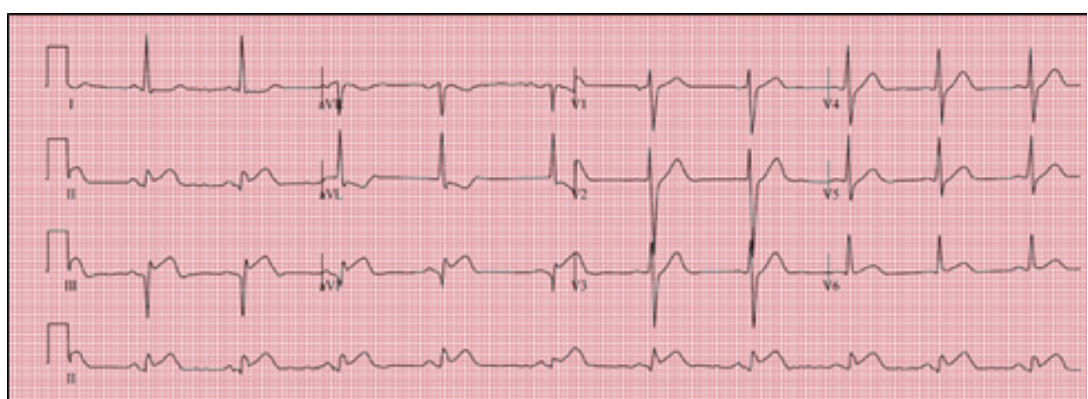

Figure 1.12-Lead ECG was at the Presentation. There was ST-segment elevation in inferior lead (II,III, and aVF) with reciprocal ST-segment depression in aVL, presumed as Interior STEMI.
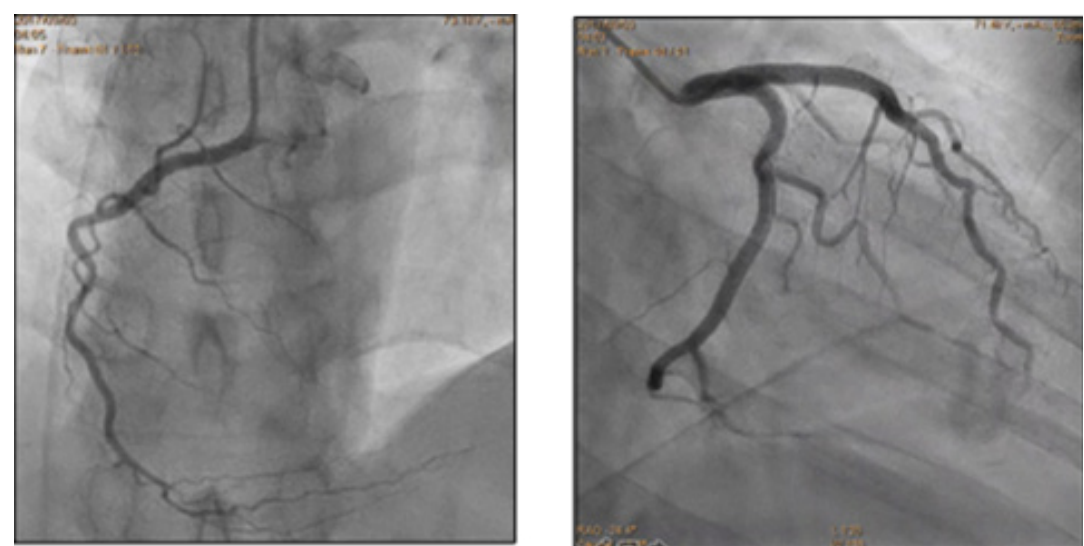

Figure 2. These was Diagnostic Coronary Angiography (DCA) images. Right (left panel) \& left coronary angiography (right panel) was presented. There were normal epicardial arteries, including right coronary artery (RCA), left main coronary arteries (LMCA), Left Anterior Descendens (LAD), and Left Circumflex (LCx). 

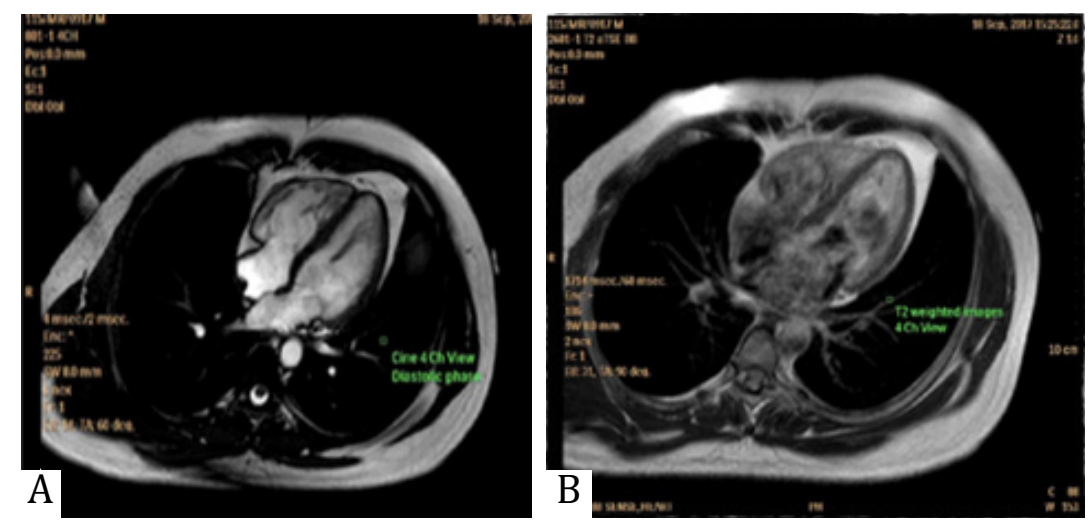

Figure 3. These were Cardiac Magnetic Resonance (CMR) images. Functional Left ventricular function and dimension were normal.(A) Pericardial effusion was loculated in left ventricle apical wall and right ventricle free wall without pericardial thickening.(B) T2 weighted images showed no increased signal density, but marked pericardial enhancement.

\section{DISCUSSION}

According to the European Society of Cardiology (ESC) guidelines, a working diagnosis of STEMI based on symptoms is consistent with myocardial ischemia (i.e. persistent chest pain) and ST-segment elevation on ECG. At a Percutaneous Coronary Intervention (PCI) capable centre, a primary $\mathrm{PCI}$ is recommended in all STEMI patients with $<12$ hours of onset and persistent ST-segment elevation, and it must be organized immediately with door to wire crossing time less than 60 minutes. ${ }^{6}$

The working diagnosis of inferior STEMI was made based on typical chest pain and ST-segment elevation on inferior lead, with reciprocal STsegment depression in the lateral lead. As a PCI capable hospital, the researchers immediately conducted the primary PCI. Normal coronary arteries on DCA and a normal serial troponin-I level made the diagnosis of STEMI unlikely. Thus, The patient was treated as a suspect of coronary spasm.

The ST-segment elevation of inferior (lead II, III, \& aVF) with lateral (lead aVL) ST-segment depression (reciprocal changes) on ECG was highly sensitive for coronary occlusion and very specific to differentiate from pericarditis. ${ }^{7}$ Diffuse ST-segment elevation is typical of classic pericarditis, but in uncommon entity especially regional pericarditis, there is a focal ST-segment elevation arising from localised irritation of the pericardium. That focal quality made the regional pericarditis particularly challenging to differentiate from the STEMI. ${ }^{8}$ A lack of reciprocal ECG changes tended to suggest it as regional pericarditis. ${ }^{9}$ The regional pericarditis presented a further challenge to diagnose due to a paucity of published diagnostic criteria. Furthermore, there were no specific ECG criteria to diagnose this condition..$^{10}$ Therefore, the clinical and ECG could not confirm the diagnosis.

In this case, the patient experienced a typical chest pain and ST-segment elevation in the inferior lead with reciprocal ST-segment depression in aVL on ECG that was consistent with an inferior STEMI. Nevertheless, an alternative diagnosis should be considered when coronary arteries and troponin-I level were normal. Therefore, a diagnostic evaluation with an advanced imaging modality was conducted.

Recent advances in multimodality noninvasive cardiac imaging have had an essential role to diagnose patients with suspected pericarditis, especially in challenging diagnoses. Critical roles of Transthoracic Echocardiogram in diagnosing pericardial pathology, and then a detailed anatomic characterisation 
of the pericardium provided by Cardiac Magnetic Resonance has aided to determine aetiology of pericardial pathology. ${ }^{10}$ Although echocardiography is considered the first choice of imaging modalities in pericarditis, CMR has ability to improve lesion visualisation and tissue characterisation of the pericardium. T2-weighted CMR imaging is superior for visualising oedema of the inflamed pericardial layers, while contrastenhanced CMR studies are useful in depicting pericardial inflammation. ${ }^{11}$

In this case, CMR was performed seven days after discharge, and it revealed a normal functional left ventricle function and dimension with normal ventricular wall motion. Pericardial effusion noted loculated at apical of the left ventricle and right ventricle free wall, without pericardial thickening (Figure 3.A). T2 weighted images showed no increased signal intensity in the myocardium but marked pericardial enhancement (Figure 3.B). The summary of the CMR examination tended to consider it as regional pericarditis.

Pericarditis could be results of the local pathology in the pericardium or systemic disease. The common cause of pericardial pathology includes viral infection, tuberculosis, and inflammation due to recent myocardial infarction. Systemic disease, such as malignancy, inflammatory responses, autoimmune disorders, and uremic state in chronic kidney disease, can precipitate acute pericarditis. Other causes include aortic dissection, pharmacologic agents (e.g. hydralazine, isoniazid), radiation treatment, and trauma. ${ }^{1,3}$ In most patients, the cause of acute pericarditis is considered to be idiopathic because the diagnostic confirmation is inconclusive. ${ }^{3}$ Regional pericarditis has been described at only a few publications and remained relatively unknown and underdiagnosed condition. Regional pericarditis can occur at the various setting with the majority of reported cases are associated with myocardial infarction and trans-mural myocardial necrosis. ${ }^{12}$

In this case, the patient had no history or clinical suspicion of tuberculosis, systemic inflammatory disease, and malignancy. With the normal coronary arteries and normal serial troponin-I, the suspicion of myocardial infarction associated pericarditis became unlikely. We did not perform any specific etiological evaluation for the clinical diagnosis of regional pericarditis in this patient. As a result, the aetiology of pericarditis, in this case, remained idiopathic.

According to ESC Guidelines, aspirin or NSAIDs have been recommended as the firstline therapy for acute pericarditis. If the clinical diagnosis has been conducted, symptomatic treatment with aspirin or NSAIDs should be initiated. Aspirin 750-1000 mg three times a day or ibuprofen in a dose of 600 to $800 \mathrm{mg}$ orally three times a day were preferred for the patient with discontinuation if there was no longer pain after two weeks. Colchicine could be added if the patient had no response to empirical NSAIDs. Colchicine was recommended at low, weight-adjusted doses to improve the response to medical therapy and to prevent recurrences. Colchicine was administered as a 2 to $3 \mathrm{mg}$ oral loading dose followed by $0.5 \mathrm{mg}$ once a day (bodyweight $<70 \mathrm{~kg}$ ) or twice a day (bodyweight $>70 \mathrm{~kg}$ ) for three months. ${ }^{5}$

Patients with acute idiopathic or viral pericarditis generally have an excellent longterm prognosis. Recurrences are the most common complication following pericarditis. Immune mechanisms appear to be of primary importance in the majority of cases. ${ }^{13}$ Cardiac tamponade rarely occurs in patients with acute idiopathic pericarditis and is more common in patients with a specific underlying aetiology such as malignancy, tuberculosis or bacterial infection. Constrictive pericarditis may occur in about $1 \%$ of patients with acute idiopathic pericarditis and is also more common in patients with any specific aetiology. ${ }^{14}$

In this case, the researchers initially treated the patient with calcium-channel blockers (diltiazem slow release $200 \mathrm{mg}$ a day) and nitrates (isosorbide dinitrate $5 \mathrm{mg}$ twice a day) as a suspect of coronary artery spasm. When the clinical diagnosis was confirmed, the empirical NSAIDs was started. The response to the therapy was excellent. Clinical and TTE evaluation was 
conducted after treatment, and it revealed a preserved left ventricle and right ventricle function without sequel of the last illness.

\section{CONCLUSION}

The researchers reported an exceptional case of regional pericarditis with typical chest pain and focal pattern of ST elevation with reciprocal ECG changes which was initially misdiagnosed to STEMI. At that time, as the PCI capable hospital, a primary PCI was immediately conducted. An alternative diagnosis was considered when the DCA before primary PCI revealed a normal coronary artery and troponin-I. CMR was also conducted to confirm the diagnosis and found an uncommon form of the pericardial disease, the regional pericarditis. After the clinical diagnosis had been organized, the patient was treated with empirical non-steroidal anti-inflammatory drugs (NSAIDs) for three weeks, and the result was excellent. The advanced cardiac imaging modalities such as TTE and CMR may be required to evaluate the abnormality of the pericardium in the suspicion of regional pericarditis.

\section{CONFLICT OF INTEREST}

The authors declared that there was no conflict of interest regarding the publication of this article.

\section{ACKNOWLEDGEMENT}

The authors would like to express deep gratitude to doctor Mochammad Yusuf Alssagaff, a cardiologist and a mentor who provided advice, enthusiastic supports, and significant critiques for this case report.

\section{REFERENCES}

1. Snyder MJ, Bepko J, White M. Acute pericarditis: Diagnosis and management. 2014;89(7):553-60

2. Xanthopoulos A, Skoularigis J. Diagnosis of acute pericarditis. e-Journal Cardiology Practice. 2017;15(15).

3. Khandaker $\mathrm{MH}$, Espinosa RE, Nishimura RA, Sinak LJ, Hayes SN, Melduni RM, et al. Pericardial disease: Diagnosis and management. Mayo Clinic Proceedings. 2010;85(6):572-93.

4. Masek KP, Levis JT. ECG diagnosis: Acute pericarditis. The Permanente Journal. 2013;17(4):e146.

5. Adler $Y$, Charron $P$, Imazio $M$, Badano L, Barón-Esquivias G, Bogaert J, et al. 2015 ESC guidelines for the diagnosis and management of pericardial diseases. European Heart Journal. 2015;36(42):2921-64.

6. Ibanez B, James S, Agewall S, Antunes MJ, Bucciarelli-Ducci C, Bueno H, et al. 2017 ESC guidelines for the management of acute myocardial infarction in patients presenting with ST-segment elevation. European Heart Journal. 2018;39(2):119-77.

7. Bischof JE, Worrall C, Thompson P, Marti D, Smith SW. ST depression in lead aVL differentiates inferior ST-elevation myocardial infarction from pericarditis. The American Journal of Emergency Medicine. 2016;34(2):149-54.

8. Youssef G, Khouzam S, Sprung J, Bourke DL. Regional pericarditis mimicking myocardial infarction. Anesthesiology : Journal of the American Society of | Anesthesiology . 2001;95:261-4.

9. Rechenmacher S, Jurewitz D, Southard J, Amsterdam E. Barking up the wrong tree: Regional pericarditis mimicking STEMI. The American Journal of Medicine. 2013;126(8):679-81.

10. Alhammouri AT, Omar BA. Regional pericarditis mimicking inferior myocardial infarction following abdominal surgery. Case Reports in Medicine. 2014;2014:10-3.

11. Klein AL, Abbara S, Agler DA, Appleton CP, Asher CR, Hoit B, et al. American society of echocardiography clinical recommendations for multimodality cardiovascular imaging of patients with pericardial disease: Endorsed by the society for cardiovascular magnetic resonance and society of cardiovascular computed tomography. Journal of the American Society of Echocardiography. 2013;26(9):965-1012.e15.

12. Bogaert J, Francone M. Pericardial disease: 
Value of CT and MR imaging. Radiology. 2013;267(2):340-56.

13. Dorfman TA, Aqel R. Regional pericarditis: A review of the pericardial manifestations of acute myocardial infarction. Clinical Cardiology. 2009;32(3):115-20.

14. Daskalov IR, Valova-Ilieva T. Management of acute pericarditis: Treatment and follow-up. e-Journal Cardiology Practice. 2017;15(16). 